UDC 811.11' 33

DOI https://doi.org/10.32838/2710-4656/2021.5-1/32

Skichko A. S.

National Technical University of Ukraine «Igor Sikorsky Kyiv Polytechnic Institute»

\title{
LINGUOCULTURAL PECULIARITIES OF THE ENGLISH LINGUISTICS PICTURE OF THE WORLD
}

Nowadays, it is impossible to imagine the learning of a foreign language without involving cultural aspects of the studied nation. That is why, the topicality of this article is directly related to the linguistics and conceptual picture of the world that depict the peculiarities of mentality, prejudices, customs, traditions jointly with the lingual peculiarities and its verbalization. Linguoconceptology is engaged in the study of these two phenomena and the linkage of culture and language that influence the coinage of stereotypes as well-grounded notions within each specific culture.

$L P W$ is capable of depicting current trends and changes that happened in society since it is based on human cognitive ability and is unique for each individual. However, at the same time is said that $L P W$ possesses universal traits, has semantic representation in the form of words or state expressions, is detailed, static and in all cases is orally verbalized. In its structure, there are nominative, functional, figurative and phonosemantics elements that are formed under the influence of national mentality and stereotypes. Regarding another term "conceptual picture of the world that is similarly close to the LPW, it is worthy to mention that the main elements on which CPW is based are "concepts", "beliefs" and "opinions". In contradictions to LPW, the conceptual picture of the world has conceptual representation, is more dynamic, multifunctional, extensive and flexible. Moreover, there are some cases when $C P W$ can not be represented and verbalized during oral communication. Nevertheless, in order to conduct valid research in the domain of cognitive linguistics, especially in terms of concept, it is necessary to involve and evoke the theoretical information of linguistics picture of the world and conceptual picture of the world.

Key words: linguistics picture of the world, conceptual picture of the world, concept, stereotypes, national mentality.

Statement of the problem. Modern linguistics research is concentrated on the detailed study of language abilities to reflect the cultural processes in different domains. While discovering a new language it is impossible, for example, to understand the meaning of specific units like proverbs, set expressions, phrasal verbs, phraseological expressions without knowing at least some cultural facts about the nation and country. That is why, over time researchers aimed to discover the nature of the terms "linguistics picture of the world" and "mentality".

Research analysis. Linguistics picture of the world and conceptual picture of the world have repeatedly been the subject of scientific research because of the undeniable connection of language and culture. Famous researchers like W. Humboldt, L. Weisberber, G. Lakoff, O. Selivanova, D. Siroka, J. Bartminski, A. Gurevich, Z. Popova and I. Sternin, A. Ufimzeva have investigated their characteristics, topicality, structure, classification, main traits and features.

The purpose of the article is to describe the peculiarities, main traits and structure of linguistics picture of the world and conceptual picture of the world.
Presenting main material. It is obligatory to mention that the linkage between language and culture is undeniable since language is reflected in the culture and vice versa. It is an interesting fact that people who live within one ethnic group and speak the same language can find tools and language resources in order to describe natural processes, form nominations of subjects, reveal and show their feelings, etc. In such a way, they obtain the same word perception that is formed with the help of language and is fixed in their mentality at a certain level.

Linguo-conceptology is a relatively new science that was formed on the verge of cognitive linguistics and cultural studies. This point of view adheres to O. Selivanova, she also considers that the main aim of this science is to discover and describe different concepts as well as their language means of representation. What is more, conceptualization places the main role within this domain, it is the process of human's cognitive activity that is based on reflection and structuralization of the obtained experience and some judgments about the surrounding world and objects that reflect reality [6, p. 403]. The target aim of the lin- 
guo-conceptology studies is the notion "linguistic picture of the world" (LPW) through the prism of language and culture linkage and the mind's influence on the conveying and adoption of new stereotypes in relation to the world changes.

D. Siroka is persuaded that Slavic scientific schools, particularly Polish, Czech, Russian and Ukrainian, have contributed a lot to the development of ethnolinguistics and the production of valuable theoretic background in the field of LWP during the last decades. Moreover, modern researchers are interested in the detailed examination of all ethnolinguistics peculiarities, since this domain cannot exist independently without the connection of social, psychological, anthropological, cognitive and cultural sciences [17, p. 297].

H. Herz was the first one who used the term "picture of the world" in 1959 while he was discovering the principles of "physical picture of the world" peculiarities and functioning. He put forward the definition that LSW is a set of internal images of external subjects that may give a particular connotation and description of these objects mood and behavior [2, p. 198].

W. Humboldt writes that the abilities of each language are unique and extraordinary since during the process of things nomination the linguistic picture of the world is conveying and forming for the bearers of the same language. For each individual language is regarded as something objective, but if things are known to them, it transforms into a subjective notion that acquires a one-sided aspect of representation. The LSP is an ultimate result of the human's cognitive abilities as well as mental world perception and its representatives are speakers of the same nations or ethnic groups [13, p. 412-414]. L. Weisberber [19] was a follower of W. Humboldt's theory and put his own efforts in order to develop his opinions and enrich the study of the linguistic picture of the world with the right taxonomy, approach, classification as well as theoretical background. He was the first who introduced this term in the linguistics domain in 2004 while developing the LPW grounded postulation.

Anusiewicz et al. interpret it as formed opinions and word perception that are fixed in language with the help of verbal and non-verbal means. Very often these beliefs are depicted in the word meaning and lexical structure, influenced by specific aspects and mood that come from the non-linguistic world [9, p. 28]. Bartminski [1] believes that LPW absorbs only those phenomena, which are highly necessary for the cultural groups, that is why, they will be deeply grounded into their language. M. Heidegger was inclined to think that every person has his own "picture of the world" and put into it individ- ual feelings, aspirations, desires and in the general form it through a unique and well-founded point of view [21, p. 49-50].

A.S. Hurevich thinks this term is capable of gathering and depict all sets of beliefs about the surrounding world in the chaotic manner of existence that all individuals transform and interpret through their own world and culture perception with involvement of emotional component and gained experience. As a result in the end they create the well-structured picture of the world that coined under the complex mentality approach [3, p. 215]. Z.D. Popova and A.Sternin define the term "national mentality" as a collective aspect of recognizing the new changes in the surrounding world as well the novelties that are grounded in real life; its background is based on a set of social stereotypes. They assume that the same situations can be reflected and perceived through different levels of mentality and in multiple ways. National mentality works as though to make people see and notice one thing, while not paying any attention to others [5, p. 44].

The existing postulates about the human's ability to discover the world unconsciously may seem a little bit confusing but each process of learning or obtaining a piece of new information based on consciousness, that's why unconscious knowledge in that specific cases is regarded as an oxymoron [10, p. 139]. Today the researches that concern mentality and mental process in general in the field of cognitive and psychoanalytic domains move on different trajectories. For example, cognitivists believe that our mind is capable of reflecting only unconscious things, while psychoanalysts are persuaded that every aspect of the unconscious is the result of mental processes. That is why, from the perspective of the psychoanalytic, our mind possesses a unique ability to retain the unconscious part where former memories, aspirations, desires, beliefs and emotions lie [18, p. 13]. Consequently, we can assume that "mentality", the key component of the linguistic picture of the world, is a multifunctional notion that consists of a former received individual as well as a collective experience that reflects the person's own needs, desires and emotions in relation to multiple life situations.

From our standpoint, together with the examination of mentality influence on the LPW, it would be necessary to jointly revise the meaning and affection of stereotypes on it as well. In each domain, this term has different theoretical justification and approaches of its development but will reconsider only those ones that fall under the scope of our scientific interest: discourse analysis, linguistics, psycholinguistics and semantics. 
Scollon and Scollon (2000) from the discourse analysis perspective define the term "stereotype" as the act of overgeneralization of the received information from the surrounding world as "cultural ideological statements". They hold on to the hypothesis that stereotypes appear when the individual encounters the two opposite discourse systems [16, p. 155].

In view of linguistics, the representation of stereotypes in language can comprise ethnic slurs, so-called disparaging words. Their main aim is to converge new negative mental images through the unknown lexicon and vocabulary, realizing in communication. In most cases, the next linguistic techniques are very common for introducing diverse patterns: associations, metaphorical and metonymic transfer and transformation. For example, cent 'North American', aizer 'a person from Azerbaijan', etc [8, p. 46-49].

Psycholinguistics is a science that is close to cognitive linguistics, it studies all possible linkages between mind and language. It regards the individual characteristics of each speaker and not his belonging to the ethnic group as a social unit, as well his linguistic performance is discovered that is represented by the strength or weakness of the common social mental apparatus [11, p. 2]. Gumperz [12] studying the paralanguage levels detects that every stereotype can occur because of inappropriate intonation.

Semiotics examines stereotypes from the point of view of the detected semiotic patterns that are based on symbols and signs. In short, stereotype introduces as an active process that is capable to reflect outcomes of communicative behavior jointly with symbols and signs representation, that are limited in number and are represented according to social norms and standards [15, p. 4].

According to M. Lebedko, all stereotypes can be divided on:

- Social, are based on social opinion;

- Political, are formed on the observation of the official's behavior;

- Cultural, stand on the influence of culture process of the world perception;

- National, are found on collective beliefs creation;

- Behavioral, depend on the individual and personal characteristics;

- Geographical, particularly based on territory/ geography/region;

- Professional, based on the professional experience and field evaluation;

- Ethnical, namely are hinged on gender, age, race and ethnicity [15, p. 4].

As a result of represented theoretical searching, we can admit the mentality and existing stereotypes are the powerful and meaningful structural units of the linguistics picture of the world since with their help it is possible to trace how specific lexis, set expressions, phrasal verbs, metaphorical utterances, etc. are formed. Because of individual and common influence on their structure, it is also possible to examine their background and origins.

Lakoff [14] in his monograph "Women, fire and dangerous things" represents the opinion that each linguistic picture of the world is individual as well as dynamic and is capable to reflect, create and ground stereotypes. Moreover, to his point of view, the LPW possesses universal traits to depict the current trends, needs, modes, desires and aspirations of modern linguistics society and its representatives. He believes that there are clear differences between the notions "definition knowledge" and "encyclopedic knowledge" since the first one shows and reveals the basic traits of words, while the second one reflects accidental characteristics of words $[14$, p. 17-40]. That means that in most communicational situations when speakers represent their thoughts, they do not think a lot about the true meaning and correct definitions of the word combinations, so it seems a natural and spontaneous act. They tend to back on their intuition as well as the previous received experience that was obtained throughout the cognitive perceptions and contextual realization of certain linguistic units.

Scholars in the domain of cognitive linguistics, Z.D. Popova and I.A. Sternin, supposed to believe that the linguistic picture of the world has specific functions, particularly interpretive and regulatory since it can affect the vision of reality and serves as a universal direction of the human life-being. Taking into consideration the previous regarded information, they developed and formed the LWP key elements that characterize its structure:

- nominative means of language, namely phraseological units, lexemes, set expressions; and the lack of these nominative means of expression, the second subtype that is characterized by the lacunas presence;

- functional means of language that influence the composition of the most frequent linguistic units and selection of the needed vocabulary and phraseological elements to form the communication expression;

- figurative means of language that depicts national imagery, different shadows of the figurative meaning, the inner structure of the linguistic units that find its representation within various language structure;

- the last key element is phonosemantics of language [5, p. 64]. 
Differences between LPW and CPW

\begin{tabular}{|cc|}
\hline LPW & CPW \\
\hline Possesses universal traits & Reflects the currents trends \\
\hline Has semantic representation (words/expression) & Has conceptual representation \\
Conservative, detailed & Extensive, multifunctional \\
\hline Static, stable & Dynamic, flexible \\
\hline Finds its oral representation & cannot be represented orally \\
\hline
\end{tabular}

Nowadays, together with the term "linguistics picture of the world" appears very often another similar but diametrically opposite term "conceptual picture of the world".

In most cases, the CPW is represented as a well-developed structure that consists of various concepts, particularly notions and beliefs, that are organized on the basis of the human cognitive perception of the surrounding world. We have already covered the approaches and theoretical justification of the term "concept" in the first point of this chapter, so here we would like to discover and study the peculiarities, characteristics and differences between these two pictures of the world.

$\mathrm{N}$. Ufimzeva is persuaded that the conceptual picture of the world is based on the information that was received and decoded from the surrounding world and was reflected in the various language concepts, while the linguistic picture of the world is represented in the semantic level that consists with the multiple words and expressions in the strict frames of studied language [7, p. 110].

The CPW is more extensive and multifunctional since during its creation different types of thinking are involved, and it is not obligatory that each language pattern finds its lingual or oral representation within each communicative act. Sometimes there are situations when the concept is formed and structured by the speaker and his mentality perception, but do not have the means in order to be represented in real life at the moment of speaking because of the difficult nomination [4, p. 12].

Carefully considering various theoretical approaches toward differentiating the peculiarities of the linguistic picture of the world and conceptual picture of the world, to our opinion, it will be logically to include and put this information in the following table 1.

Of course, between these two pictures, there are visible differences, but we think that they are interdependent and must be studied jointly. Due to such a complex approach let study thoroughly the semantic realization of the concepts as well as a cultural influence on its formation through the prism of national and individual mentality, with the stereotypes, prejudice, beliefs and emotional involvement.

$\mathrm{N}$. Ufimzeva [7] thinks that there is a tight relation and connection between LPW and CPW. Sometimes during the communication acts the linguistic picture of the world can influence the development of the conceptual picture of the world because of the different ways of thinking and world perception.

Consequences and proposals. As a consequence, we may say that the linguistic picture of the world and the conceptual picture of the world are closely related in meaning and stricture. While conducting every linguistic research, it is necessary to rely on them both, since in the final variant it will be possible to get valid and profound results.

What concerns our scientific researches, we conclude that it is obligatory to conduct our research with involvement and through the prism of linguistic picture of the world, since it profoundly reveals the peculiarities and specificity of the mental processes and stereotypes of the native English speakers, aw well as it reflects the reflection of the linguistic MOTIVATION concepts on all levels of language.

\section{References:}

1. Бартминьский Е. Базовые стереотипы и их профилирование. Стереотипы в языке, коммуникации, культуре: сб. статей / сост. и отв. ред. Л.Л. Федорова. Москва: РГГУ, 2009. С. 11-21.

2. Герц Г. Принципы механики, изложенные в новой связи. Жизнь науки: Антология вступлений к классике естествознания. Москва: Изд-во АН СССР, 1959. С. 206-210.

3. Гуревич А.Я. Исторический синтез и школа «Анналов». Москва: Издательство «Индрик», 1993. 319 с.

4. Космеда Т.А. Аксіологічні аспекти прагмалінгвістики: формування і розвиток категорії оцінки. Львів: ЛНУ ім. і. Франка, 2000. 350 с. 
5. Попова 3.Д., Стернин И.А. Язык и сознание: теоретические разграничения и понятийный аппарат. Язык и национальное сознание. Вопросы теории и методологии. Воронеж : ВГУ, 2002. С. 8-50.

6. Селіванова О.О. Сучасна лінгвістика: напрями та проблеми. Полтава: Довкілля-К, 2008. 711 с.

7. Уфимцева А.А. Роль лексики в познании человеком действительности и в формировании языковой картины мира. Роль человеческого фактора в языке: Язык и картина мира / отв. ред Б.А. Серебренников. Москва: Наука, 1988. С. 108-140.

8. Фофин А.И. Русские и французские этнофолизмы

как вербальные знаки национальной нетерпимости. Вестник Иркутского государственного лингвистического университета. Иркутск: ИГЛУ, 2008. о 1. С. 45-51.

9. Anusiewicz J., Dabrowska, A. Językowy obraz świata i kultura. / In Anusiewicz J., Dabrowska, A. (eds.). Wrocław: Wydaw. Uniwersytetu Wrocławskiego, 2000. 370 s.

10. Boag S., Brakel L.A.W., Talvitie, V. Psychoanalysis and philosophy of mind : Unconscious mentality in the twenty-first century. London: Karnac Book, 2015.300 p.

11. Field J. Psycholinguistics. A resource book for students. London and New York: Routledge. Taylor and Francis group, 2006. $231 \mathrm{p}$.

12. Gumperz J.J. Interethnic communication. Intercultural discourse and communication / S.F. Kiesling \& C.B. Paulston (eds.). Malden, MA, USA: Blackwell Publishing, 2005. P. 33-44.

13. Humboldt V. Language and philosophy of culture. Moscow: Progress, 1985. $451 \mathrm{p}$.

14. Lakoff G. Women, Fire, and Dangerous Things. Chicago: The university of Chicago Press, 2006.605 p.

15. Lebedko M. Theory and practice of stereotypes in intercultural communication. Critical cultural awareness : Managing stereotypes through intercultural (language) education./ Houghton S. A., Furumura Y., Lebedko M., \& Li, S. (eds.), 2013. p. 4-23.

16. Scollon R., Scollon S. W. Intercultural communication: A discourse approach. Beijing: Foreign Language Teaching and Research Press, 2000. p. 155.

17. Siroka D. A linguistic picture of the world and expression of emotions through the prism of expressive lexis. Journal of Education Culture and Society. Wroslaw: Pro Scientia Publica, 2013. No. 2. 397-308 p.

18. Talvitie, V. The Freudian Unconscious and Cognitive Neuroscience. From Unconscious Fantasies to Neural Algorithms. London: Karnac LTD, 2009. V. 17, № 3. 93-96 p.

19 Weisberber J. Mother tongue and building the spirit. Muttersprache und Geistesbildung. Translated from German, foreword and commentary by O.A. Radchenko. 2nd edition. Moscow: Russia, URSS Publication, 2004. 169 p.

20. Wierzbicka A. Semantics, culture, and cognition: Universal human concepts in culture-specific configurations. Oxford \& New York: Oxford University Press, 1992. 487 p.

21. Xajdegger M. Vremya i bytie [Time and Being], Moskva: Respublika, 1993. 447 p.

\section{Скічко А. С. МОВНО-КУЛЬТУРНІ ОСОБЛИВОСТІ АНГЛІЙСЬКОЇ ЛІНГВІСТИЧНОЇ КАРТИНИ СВІТ}

У наш час неможливо уявити вивчення іноземної мови без залучення культурних аспектів ї̈ народу. Саме тому актуальність цісї статті безпосередньо пов'язана з мовною та концептуальною картиною світу, що відображає особливості ментальності, сформованих упереджень, звичаїв, традицій разом із мовними особливістями та ї̈ вербалізацією. Лінгвоконщептологія займається вивченням цих двох явищ та зв'язком культури та мови, які впливають на вироблення стереотипів як обгрунтованих уявлень у межах кожної конкретної культури.

МКС здатна зобразити сучасні тенденції та зміни, щуо відбулись у суспільстві, оскільки вона базується на когнітивних здібностях людини та є унікальною для кожної людини. Проте водночас більшість учених вважають, що МКС притаманні універсальні риси, семантичнареалізація увигляді слів або виразів, що відображають душевний стан, також вона є детальною, статичную і у всіх випадках має усне вираження. У $і ̈$ структурі присутні номінативні, функціональні, образні та фоносемантичні елементи, що формуються під впливом національної ментальності та стереотипів. Вважається, щяо термін «концептуальна картина світу» є близьким і навіть деякою мірою синонімічним до МКС. Варто згадати, що основними елементами, на яких базується ККС, $\epsilon$ «концепти», «переконання» та «думки». На противагу МКС, концептуальна картина світу має концептуальне вираження, є більш динамічною, багатофункиіональною, маштабною та гнучкою. Більше того, існують випадки, коли ККС може не мати усного вираження під час спілкування. Тим не менше, для проведення достовірних досліджень у галузі когнітивної лінгвістики, особливо коли дослиджуюються концепти, необхідно залучати теоретичну інформацію з приводу лінгвістичної картини світу та концептуальної картини світу.

Ключові слова: мовна картина світу, конщептуальна картина світу, концепт, стереотипи, начіональний менталітет. 